\title{
ADR AND CIVIL PROCEEDING IN ITALY 2021, POTENTIAL DEVELOPMENTS COMMISSIONE LUISO ${ }^{1}$
}

\section{MEIOS ALTERNATIVOS DE RESOLUÇÃO DE CONFLITOS E PROCESSO CIVIL NA ITÁLIA NO ANO DE 2021: POTENCIAIS DESENVOLVIMENTOS PELA COMISSÃO LUISO}

Giovanni Matteucci JD, B\&ED, Diploma in Economics, IAPMMHJMC, professional commercial mediator and trainer in mediation; advisor in small/medium firm financial crisis prevention. Bologna, Italy. Email: adrmaremma@gmail.com

\begin{abstract}
Italy aims to reduce the length of civil trials. In 2021 the government has appointed the Commissione Luiso, which -with regard to out-of-court methods of dispute resolution- recommends tax incentives, increase of matters subject to mandatory mediation, enhancement of court-appointed-mediation, clarification of the mediation proceeding requirements to make it more effective, involvement of the public administration, quality of training.
\end{abstract}

KEYWORDS: ADR, mediation, civil proceeding, court annexed mediation, training, Italy, Luiso.

RESUMO: A Itália, no intuito de reduzir o tempo de duração dos julgamentos de causas cíveis, vem adotando algumas estratégias. Em 2021, o governo italiano instaurou a Comissão Luiso, a qual, no que diz respeito aos métodos extrajudiciais de resolução de litígios, possui as seguintes recomendações e/ou objetivos: (i) incrementar os incentivos fiscais para aqueles que se valerem de procedimentos de mediação, (ii) aumentar as matérias sujeitas à mediação obrigatória, (iii) gerar maior clareza quanto aos requisitos do processo de mediação com o intuito de torná-lo mais eficaz, (iv) aprimorar a mediação realizada pelas Cortes; (v)

\footnotetext{
${ }^{1}$ Artigo recebido em 03/06/2021, sob dispensa de revisão.
} 
aumentar a participação da Administração Pública, (vi) promover uma formação de mediadores com maior qualidade.

PALAVRAS-CHAVE: meios alternativos de resolução de conflitos, processo civil, mediação realizada pelo Tribunal, treinamento, Itália, Lusio.

The Covid-19 pandemia raised social and economic problems all over the world, in Europe and in Italy. To help recovery, the European Union has set up extensive credit lines for all member countries, the disbursement of which is linked to the achievement of specific goals. Among the latter, the efficiency of civil justice.

To this purpose, on March 12, 2021 the Italian government set up the "Commission for the elaboration of proposals on civil proceedings and alternative dispute resolution procedures", chaired by Prof. Francesco Paolo Luiso, who delivered his report on May 24, 2021. ${ }^{2}$ Along with other topics, the commission paid considerable attention to out-of-court dispute resolution proceedings. In Italy, mainly arbitration, assisted negotiation and mediation ${ }^{3}$, whose rules are hoped to be collected in a single text.

Arbitration is a very ancient legal institution but, in Italy, it is little used. ${ }^{4}$ The arbitration award has the same effect as a judgment, which is why, according to the Luiso

\footnotetext{
2 Italian Ministry of Justice

https://www.giustizia.it/cmsresources/cms/documents/commissione_LUISO_relazione_finale_24mag21.pdf

3 In Italy, arbitration is governed by articles $806-840$ of the Code of Civil Procedure; assisted negotiation was introduced by Law decree 12.9.2014, no. 132, converted with changes by Law 10.11.2014, no. 162; mediation, already provided by many articles, starting from 183 c.p.c., was regulated as a mandatory condition of procedeability (so called "mandatory mediation") for disputes in certain available civil rights by Legislative Decree 28/2010.

Giovanni Matteucci, "Italy Is Doing It, Should We Be? - Civil and Commercial Mediation in Italy" in "Contemporary tendencies in mediation",page 20, Dykinson 2015, Universidad Carlos III de Madrid http://earchivo.uc3m.es/handle/10016/20429

Giovanni Matteucci, "Civil mediation, how to kick-start it; the Italian experience - Training, compulsory, tax relieves, control" Revista de EMERJ Escola da Magistratura do Estado do Rio De Janeiro, v.19.4 2017 https://www.emerj.tjrj.jus.br/revistaemerj_online/edicoes/revista19_n4/revista19_n4_78.pdf D'Urso Leonardo and Canessa Romina, "The Italian Mediation Law on Civil and Commercial Disputes", a description of the mediation procedure under the Legislative Decree 28/2010 (D.Lgs. 28/2010) and the Ministerial Decree 180/2010 (D.M. 180/2010), along with the translation of laws in English 2017 www.mondoadr.it/wp-content/uploads/The-Italian-Mediation-Law.pdf Alessandro Bruni, "Mediation in Italy", in Concilia 2019, http://www.concilia.it/mediation_2019.pdf Luigi Cominelli and Arianna Jacqmin, "Civil and commercial mediation In Italy: Lights and Shadows", in Revista de EMERJ Escola da Magistratura do Estado do Rio De Janeiro V.22 - N.1, 2020 https://www.emerj.tjrj.jus.br/revistaemerj_online/edicoes/revista_v22_n1/revista_v22_n1_11.pdf ${ }^{4}$ Monica Iacoviello, Paolo Di Giovanni, Tommaso Faelli and Vittorio Allavena, "Alternatives to litigation in Italy", Lexology, March 2021
} 
Commission's report, it is necessary to ensure that the arbitrators are more neutral and reliable. They should therefore disclose any possible links or common interests with the parties and their lawyers (duty of disclosure). In addition, in ritual arbitrations, the possibility of issuing provisional measures should be recognised, following the will of the parties, as provided for in other European Legal systems.

Assisted negotiation is used almost exclusively for consensual solutions of legal separations of married people, end of civil effects of marriage, modification of the conditions of separation or divorce. The Luiso Commission suggests to extend the use of assisted negotiation also to agreements relating to underage children born out of the marriage.

The main attention paid by the Luiso Commission's report to ADRs is focused on mediation, with a wide range of proposals, some of which, if accepted, would have positive disruptive effect:

-. tax incentives

-. increase of the subjects covered by mandatory mediation;

-. more effectiveness of mediation ordered by the judge;

-. clarification of the mediation proceeding to make it more effective;

- involvement of the public administration;

- quality of training.

\section{"Tax incentives}

The Legislative Decree 28/2010 provides in art. 17.c.2 "All acts and documents relating to the mediation procedure are exempt from the 'imposta di registro' and from all expenses, taxes or fees of any kind and nature" / c.3 "The record of the agreement is exempt from 'imposta di registro' up to the value of euros 50,000.00, otherwise the taxi s due for the exceeding value". The Luiso Commission recommends to increase the limit to euros $100,00.00$.

Article 20 of Legislative Decree 28 already provides for tax credit, in favor to the parties to the mediation proceeding, proportionate to the compensation paid to the mediation

https://www.lexology.com/library/detail.aspx?g=cee46dd8-c9bc-46ab-99daf8418c62cebb\&utm_source=Lexology+Daily+Newsfeed\&utm_medium=HTML+email+-+Body++General+section\&utm_campaign=Lexology+subscriber+daily+feed\&utm_content=Lexology+Daily+Newsf eed+2021-04-15\&utm_term= 
provider, up to a maximum of euro 500.00 in case of agreement, halved in case of failure. However this provision has always been subject to the availability in a Justice Fund, as set out by the Minister of Justice. Such availability has never occurred.

The Luiso Commission recommends

-. to extend this tax credit to cover the costs of the assisting lawyer in mediation;

-. to recognize the legal aid for the costs of legal assistance in mediation for those entitled, a provision particularly welcomed by the lawyers;

-. to return to the parties the fee paid at the beginning of the judicial proceedings, following an agreement in mediation related to that dispute (implicit aid to the mediation requested by the judge);

-. to provide a small compensation for the management of the first mediation meeting (up to now the lawyer is paid, the mediator works for free), tax credit for the parties, if attending the meeting.

\section{Increase of matters subject to mandatory mediation}

Mediation belongs to the Italian legal tradition. But since the 1930, when it was no longer taught in universities for about seventy years, we have forgotten about it. It is provided for in article 183 of the Code of Civil Procedure (first attendance of the parties in the civil judicial proceeding), but it has been used less than formally; it is scattered here an there in the legal system, but its management is entrusted to professionals skilled in adversarial techniques; it was provided for by Legislative decree 5/2003 ("Reform of company law"), related to corporate, financial, banking and credit disputes (very wide fields) but it was hardly used at all (and when, in 2011, I asked lawyers why, they replied: "It was not mandatory").

At the end of 2009 there were a bit less than 6,000,000 pending civil cases in courts. In 2010 the Ministry of justice asked for the availability of 95,000,000.00 euro to deal with the compensations for excessively long trials. By the Law 69/2009 the government was given delegated powers of the use of mediation in disputes related to available civil rights. Legislative Decree 28/2010 ruled mediation as an obligatory condition for judicial proceedings in matters amounting to approximately $9 \%$ of civil cases. Strong opposition 
from lawyers, 'benign neglect' from the judiciary. ${ }^{\mathbf{5}}$. In 2013 the "OPT-OUT" mandatory mediation model was ruled: the parties, assisted by lawyers, are obliged to attend a "first" introductory meeting, during which the mediator explains them the principles of mediation and asks them if there are any particular reasons why they should not to begin the mediation. After that the parties can decide whether or not to continue. ${ }^{6}$

The Luiso Commission recommends the extension of the first compulsory mediation meeting in dispute related to contracts, in which the relationship between the parties is due to last over time: agency contracts, joint ventures, consortia, franchising, networks, partnership and subcontracting.

Voluntary recourse to mediation and assisted negotiation in individual labour disputes is also suggested.

\section{Enhancement of court-appointed mediation}

As mentioned above, when mediation, as mandatory condition for judicial proceeding, was introduced, the vast majority of judges considered it to be a "Child of a lesser God". However, apart a few judges who acted as pioneers, the judiciary at a very slow pace began to realize the usefulness of the institute. In 2011 mediations ordered by judges amounted to $2 \%$ of all procedures managed by the mediation providers. This figure rose to $10 \%$ in $2015,11 \%$ in $2016,13 \%$ in $2017,15 \%$ in 2018 and $14 \%$ in 2019 . It is very likely that mediation in Italy strengthened, thanks to the judiciary. But there is plenty of room to grow. ${ }^{7}$

Indeed, as a judge underlined, the magistrate, who settles a lawsuit in his role through a non-judicial solution, it is as if he did not work. The assessment of his/her productivity is based on the number of issued judgments; if he/she spends time to analyzing the mediability of a dispute, than makes a proposal for a solution according to article 185-bis Code of Civil

\footnotetext{
5 Giovanni Matteucci, "Mandatory mediation, the Italian experience", in Revista Eletronica de Direito Processual REDP; Periodico da Pòs-Graduacao Stricto Sensu em Direito Processual da UERJ Universidade do Estato do Rio de Janeiro (Vol. XVI 2015, page 189) https://www.epublicacoes.uerj.br/index.php/redp/article/view/19964

6 Giuseppe De Palo, "Mediating Mediation: the Easy Opt-Out Model” Tijdschrift Conflicthantering, 2020 https://kmt.mediatorsvereniging.nl/download/?id=3915

7 Giovanni Matteucci, “Mediation and judiciary in Italy 2019” in APMJ Asia Pacific Mediation Journal, 2019

/2, page 65 http://mediate.or.kr/base/data/APMJ.php
} 
Procedure, the parties reach an agreement and do not revert to court, the time he/she devoted to that case does not count for assessing his/her professionality.

The Luiso Commission recommends the court orders requesting mediation for the settlement of disputes should be recorded in the District Civil Litigation Information System (SICID). Moreover, qualified personnel should assist the judge in the assessment of the mediability of the case, an activity that originates mainly from the experience of Judge Moriconi (Court of Rome) ${ }^{8}$, the Court of Bari and the Court of Florence.

Court of Bari - Judge Mirella Delia implemented the "Integrated conciliation" in 2011, thanks to orders involving lawyers; other judges joined the initiative, law graduates helped on the computer filing of the cases and their outcomes; the local forensic engineering commission took care of the IT issues. Results:

- 914 Integrated Conciliation Resolutions issued from 01.01.2016 to 30.06.2018; of which 414 completed, 332 (80\%) without further intervention of the judge (agreement or waiver of the dispute) and only 82 (20\%) with a formal judgement,

- a free-on-line database (BDDC Banca Dati Digitale Conciliativa), with a selection of the court order and the minutes of the agreement, thanks to which it is possible to identify the main "mediation indicators".

Court and University of Florence - In 2017 the University of Florence (Dpt. of Law and Dpt. of Engineering) and the Court of Florence, commercial section, launched the "Simple Justice" project, focused on judicial mediation and on the implementation of a predictive algorithm on the "mediability" of judicial proceedings and the probability of the outcome. The project is based on the collaboration among young researchers, judges and mediators; and it is divided in four stages:

1 - analysis of court files by the researcher, who selects the files, draws up the report for each file, delivers the file and the report to the judge;

2 - referral to mediation - the judge considers whether or not to accept the researcher's proposal, draws up the order referring the case to mediation and sets the date for the next court hearing (the mediation proceeding completed) within a maximum six months period; 3 - the mediator undertakes the proceeding within the time limit set by the judge and reports every month on completed procedures;

\footnotetext{
${ }^{8}$ Massimo Moriconi, "Non solo sentenze", ed. "Il pensiero giuridico", 2020
} 
4 - return to court - the judge reviews the results of the return hearing and assesses the effectiveness of his / her previous decision.

In 2018 researchers analyzed 9,941 court files; 1,296 cases were submitted to mediation; 577 cases were resolved through mediation (6\% of the files initially analyzed). The Dpt. of Engineering - DISITLab, University of Florence is studying all the documents to develop the predictive algorithm.

In relation to this project, the following have also been quantified:

- the social impact (increase of trust in mediation by citizens and professionals) through the number of compliances of the parties to the judge's order to resort to mediation;

- the economic impact, the reduction in the average length of proceedings;

- the impact on the efficiency of justice, through the reduction on the judicial burden;

- the cultural impact (trust in mediation within the courts) through the number of mediation orders issued by judges.

Results will be published soon.

\section{Clarifications of the mediation proceeding requirements}

The Luiso Commission report underlines that the first mediation meeting must be effective and the personal presence of the parties must be expressly provided for. The lack of respect for these principles severely undermines the effectiveness of mediation in Italy. Indeed, of all the procedures started, in 2011 all the parties were present in only $32 \%$ of them; $49 \%$ in 2019 . But there still is a long way to go.

Even today, art. 8, c.1, third sentence and following, and c. 4bis of Legislative Decree 28/2010 explicitly provide the presence of the parties but the age-old habit of the layer "representing" the party in the judicial proceeding has generally prevailed over the understanding of the essence of mediation. Consideration supported by the Court of Cassation, judgment $8473 / 2019$, according to which the need for personal presence in mediation does not mean that it cannot be delegated. Therefore, the party, who, for his/her own choice or impossibility cannot attend a mediation meeting in person, can also be replaced by his/her lawyer, with a "substantial" special power of attorney, which cannot be authenticated by the lawyer himself. 
The suggested proposals are: providing for a small fee for the first information meeting; restricting the possibility of being replaced by another people only to cases of impossibility of personal presence or being replaced by another person with knowledge of the events and interests of the party; revising the penalties for non-compliance with the obligations.

It is also proposed to regulate the CTM - Consulenza tecnica in Mediazione (technical consultancy in mediation), carried out by a neutral expert and to be used, with the consent of the parties, in any subsequent judgement, in order to reduce time and costs. This practice has already been used by some courts for years.

\section{Involvement of the Public Administration}

Topic of disruptive importance. Once the Legislative Decree 28/2010 came into force, the Dpt. of Public Administration issued a memorandum (Circolare no. 9, 10.08.2012) and the Avvocatura dello Stato a memo (Circolare no. 41/2012). The Corte dei Conti, Jurisdictional Section at the Sicilian region, issued the sentence 2719, 23.07.2013. There are no other official documents on the matter.

In practice, it has become a habit among public administrations (condemned by the local courts) not to attend mediation, for fear of incurring liability for financial loss. According to the Luiso Commission, "such considerations ... have been overtaken by the approval of Article 21, Law Decree no. 76, 16.07.2020, converted by Law no. 120, 11.09.2020, which defines the area of indemnifiable damage suffered by the Administration ...to unlawful conduct of its officials ... for willful misconduct or gross neglicence, with the express purpose of avoiding the so-called fear of the public official's signature". Appropriate legislation should be enacted.

\section{Quality of training}

Another topic of absolute relevance, since knowledge is a prerequisite for any activity.

The basic course to become mediator, in Italy, according to Ministerial Decree 180 / 2010, lasts 50 hours, as in many other Western countries. 20 internships and 18-hour refresher courses every two years (16 for mediation trainers) are required. But mediation is 
a complex discipline. It is very likely that 50 hours, rather than training in mediation, would be sufficient to IN-form on the existence of mediation. 200 hours courses would be much more appropriate. 9

Aware of this inadequacy, in recent times some training bodies have started to offer courses lasting more than 50 hours (with internship). In addition, the Milan Chamber of Commerce in 2013 set up the CIM - Italian Mediation Competition (moot), in which over twenty universities now partecipate. Interest in qualified training is growing, but ADRs are not yet included among the curricular university disciplines.

The Luiso Commission recommends to strengthen initial and continuous training, to review the criteria for the accreditation on mediation and training bodies, as well as mediators, taking into account the minimum requirements underlined by the CEPEJ in 2018 and 2019. ${ }^{10}$ It also calls for university training.

The commission also suggests the presence of family mediators in all courts dealing with disputes on the subject.

Italy has an estimated population of 60 million people. There are 9,401 judges and 242,000 lawyers.

In 2019 there were:

- 2,974,684 new proceedings filed in civil courts;

- $\quad$ 147,691 civil mediation proceedings;

- $\quad 20,824$ mediated settlement agreements.

In the 2011 / 2019 period there has been

- a decrease in civil court litigation (- $4 \%$ per year), because of the economic crisis;

- a strong increase in mediation proceedings $(+18 \%$ per year $)$ and

- a strong increase in mediated settlement agreements (+14\% per year).

Nevertheless, there is wide room for their growth.

\footnotetext{
${ }^{9}$ Greg Bond: “... I have always been skeptical about one-week forty-hour mediation courses leading to accreditation and people being able to say they are qualified mediators. ... I was proud to have to do two hundred hours of mediation training, then several mediations, and coaching on those mediations before I could become accredited by the German Mediation Association (Bundesverband Mediation). I was and am convinced that this is a sign of quality" - "On the benefit of mediation training, and on getting things wrong. An interview with Ewa Chye", Kluwer Mediation Blog, 3.2019

http://mediationblog.kluwerarbitration.com/2019/03/24/on-the-benefits-of-mediation-training-and-ongetting-things-wrong-an-interview-with-eva-chye/

${ }^{10} \mathrm{CEPEJ}$ mediation tools https://www.coe.int/en/web/cepej/mediation-tools.
} 


\section{REFERENCES}

BOND, Greg. On the Benefits of Mediation Training, and On Getting Things Wrong. An Interview with Eva Chye. Kluwer Mediation Blog, 2019. Available at: http://mediationblog.kluwerarbitration.com/2019/03/24/on-the-benefits-ofmediation-training-and-on-getting-things-wrong-an-interview-with-eva-chye/

BRUNI, Alessandro. Mediation in Italy. Concilia, 2019. Available at: http://www.concilia.it/mediation_2019.pdf

COUNCIL OF EUROPE. CEPEJ mediation tools. Available at: https://www.coe.int/en/web/cepej/mediation-tools

D'URSO, Leonardo; CANESSA, Romina. The Italian Mediation Law on Civil and Commercial Disputes". ADRCenter 2017 Available at: www.mondoadr.it/wpcontent/uploads/The-Italian-Mediation-Law.pdf .

DE PALO, Giuseppe. Mediating Mediation: the Easy Opt-Out Model. Tijdschrift Conflicthantering, 2020. Available at: https://kmt.mediatorsvereniging.nl/download/?id=3915

ITALIAN MINISTRY OF JUSTICE. Commissione per l'elaborazione di proposte di interventi in materia di processo civile e di strumento alternativi. 2021 Available at: https://www.giustizia.it/cmsresources/cms/documents/commissione_LUISO_relazi one finale_24mag21.pdf

COMINELLI, Luigi; JACQMIN, Arianna. Civil and commercial mediation In Italy: Lights and Shadows. Revista de EMERJ: Escola da Magistratura do Estado do Rio De Janeiro, v. 22, n. 1, p. 11-26, january/march 2020. Available at: https://www.emerj.tjrj.jus.br/revistaemerj_online/edicoes/revista_v22_n1/revista_v 22_n1_11.pdf

MORICONI, Massimo. Non solo sentenze. Publisher: Il pensiero giuridico. 2020.

MATTEUCCI, Giovanni. Civil mediation, how to kick-start it; the Italian experience Training, compulsory, tax relieves, control. Revista de EMERJ: Escola da Magistratura do Estado do Rio De Janeiro, v. 19, n. 4, september/december 2017. Available 
Rio de Janeiro. Ano 15. Volume 22. Número 3. Setembro a Dezembro de 2021

Periódico Quadrimestral da Pós-Graduação Stricto Sensu em Direito Processual da UERJ

Patrono: José Carlos Barbosa Moreira (in mem.). ISSN 1982-7636. pp. 399-409

www.redp.uerj.br

https://www.emerj.tjrj.jus.br/revistaemerj_online/edicoes/revista19_n4/revista19_n

4_78.pdf

MATTEUCCI, Giovanni. Italy Is Doing It, Should We Be? - Civil and Commercial Mediation in Italy. In: DALLA Bernardina de Pinho, Humberto; et al. Contemporary tendencies in mediation”. Page 20. Publisher: Dykinson, 2015. Universidad Carlos III de Madrid. Available at: http://e-archivo.uc3m.es/handle/10016/20429

MATTEUCCI, Giovanni. Mandatory mediation, the Italian experience. Revista Eletronica de Direito Processual REDP. V. 16, n. 16, page 189-210. Available at: https://www.e-publicacoes.uerj.br/index.php/redp/article/view/19964 .

MATTEUCCI, Giovanni. Mediation and judiciary in Italy 2019. APMJ Asia Pacific Mediation Journal, 2019/2, page 65. Available at: http://mediate.or.kr/base/data/APMJ.php

IACOVIELLO, Monica; DI GIOVANNI, Paolo; FAELLI, Tommaso; ALLAVENA, Vittorio. Alternatives to litigation in Italy. Lexology. March 2021. Available at: https://www.lexology.com/library/detail.aspx?g=cee46dd8-c9bc-46ab-99da-

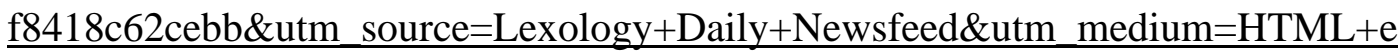
$\underline{\text { mail+-+Body+- }}$

$\underline{+ \text { General+section\&utm_campaign }=\text { Lexology+subscriber+daily+feed\&utm_content }}$ $=$ Lexology+Daily+Newsfeed+2021-04-15\&utm_term= 